\title{
30. 多用途型透析装置
}

\begin{abstract}
目 的
現在血液透析治療に用い られるダイアライザには, コイル型, 積層型, 中空繊 維型などがあるが，これに 対してコンソールタイプの 透析装置は,コイル型のた めの Recirculating Single Pass(以下 R. S. P. と略す) 方式と, 密閉型ダイアライ ザのための Single Pass(以 下 S.P. と略す) 方式の 2 種類が用いられている。こ のことは，透析装置を決定 することによって使用され るダイアライザが，ある程
\end{abstract} 度決定されてしまうことを意味し，限られた数 の装置で，多くの患者を治療する際に一つの制 約となっている.

また従来, 密閉型ダイアライザにおいてS.P. 方式で通常 $500 \mathrm{~m} l / \mathrm{min}$ の透析液流量が使用さ れているが，初期透析，大面積ダイアライザの 使用，小児，老人，合併症のある患者などにお いて，急激な溶質除去のため不均衡症候群をお こしやすく，また透析膜との接触が十分に行わ れないまま捨てられ，経済的にも不合理である といら欠点があった。

そこで我々は，これらの問題点を考慮して，

* 須田クリニック

*2 東京女子医科大学人工腎臓センター

*3 ムサシェンジニヤリング
森山芳明* 内藤正志* 須田昭夫* 江良和雄 ${ }^{*}$ 阿岸鉄三*2 太田和夫*2 彦坂幹雄 ${ }^{* 3}$ 利良川真*3

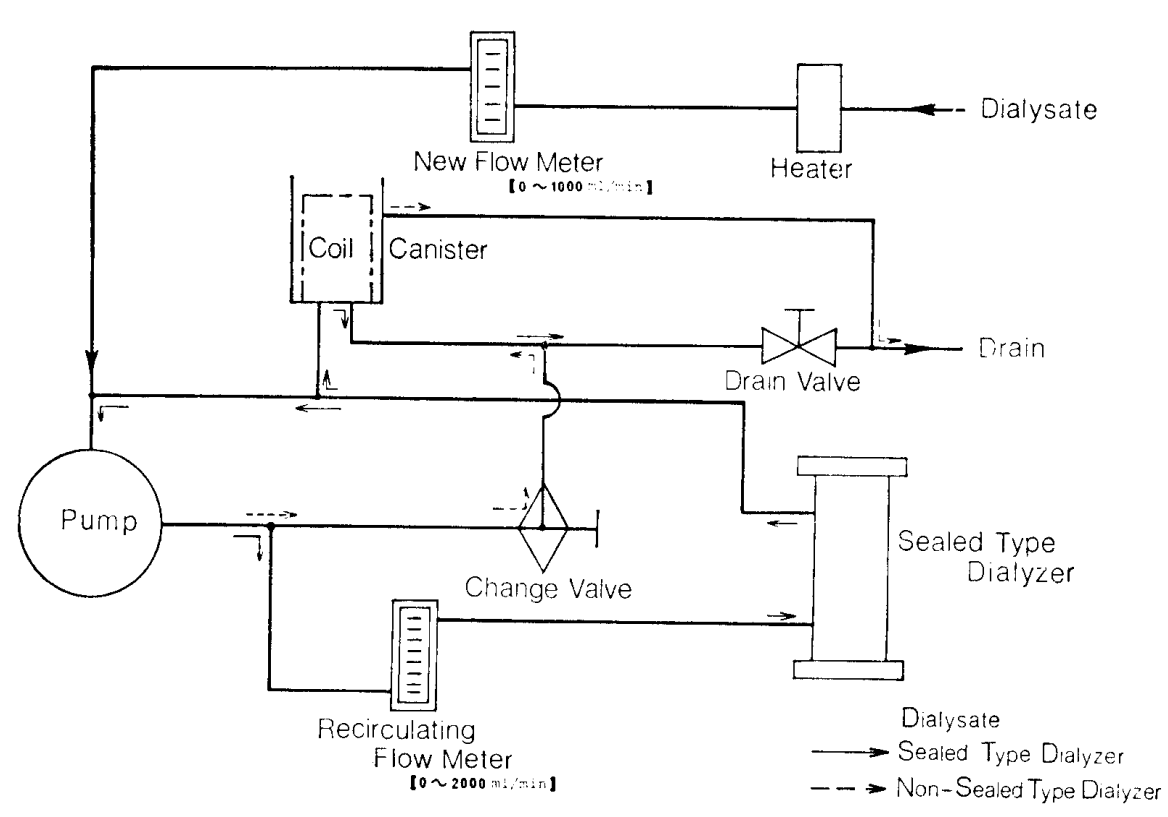

図 1

密閉型及び非密閉型いずれのダイアライザも使 用可能で, 密閉型ダイアライザの使用に際し， 透析液を一部再循環させて R.S.P.方式で使用 することができる透析装置を試作し，その透析 性能及び問題点を検討したので報告する。

\section{装置の構造及び説明}

本装置は幅 $362 \mathrm{~mm}$ ，奥行 $585 \mathrm{~mm}$ ，高さ 300 $\mathrm{mm}$ と小型で, 電源は $\mathrm{AC} 100 \mathrm{~V}, 50 \sim 60 \mathrm{H}_{2}$ で, 本体の全面に各種の計器類を装備し, 密閉型ダ イアライザのための透析液出入口を有する二つ の流量調節計に上り, 供給透析液流量（以下 $\mathrm{NQ}_{\mathrm{D}}$ と略す）は $0 \sim 1,000 \mathrm{ml} / \mathrm{min}, \mathrm{NQ}_{\mathrm{D}}$ と加 算した再循環流量（以下 $R_{\mathrm{D}}$ と略す）は 0 ～ $2,000 \mathrm{ml} / \mathrm{min}$ まで変化させることができる.

側面には直径 $180 \mathrm{~mm}$, 高さ $261 \mathrm{~mm}$ のクリア ーキャニスタを有し、コイル型などの非密閉型 
ダイアライザを使用することができる.

図 1 は本装置の内部構造を模式図に示した. 透析液供給回路と排水回路とを接続させ，密閉 型ダイアライザの使用時に排液の一部を再循環 させることができるようになっている.

透析液供給回路には新液流量計があり, 再循 環回路には再循環流量計が接続されて，それぞ れの透析液流量を任意に組み合わせて変えるこ とができる，密閉型ダイアライザと非密閉型ダ イアライザによる切り換えは Change Valeve によって行われる。図の点線の矢印が非密閉型 ダイアライザを使用した場合の透析液の流れを 示し，実線の矢印が密閉型ダイアライザを使用 した時の透析液の流れを示す。

\section{実験方法}

実験は Sealed type dialyzer において, R. S.P. 万式を用いた時の透析性能を S.P. 方式と 比較した。

Sealed type dialyzer に AHFK K-102を使 用し, 模擬透析液は水道水を $38^{\circ} \mathrm{C}$ に加温し, 模擬血液として尿素窒素 $100 \mathrm{mg} / \mathrm{d} l$, クレアチ ニン $10 \mathrm{mg} / \mathrm{d} l$ 及びビタミン $\mathrm{B}_{12} 20 \mathrm{mg} / l$ を含 んだ水溶液を用いた。模擬血液の流量は $200 \mathrm{~m} l$ $/ \mathrm{min}$ 一定として，透析液は供給量を $500 \mathrm{ml} /$ $\mathrm{min}$, 再循環流量を $500 \sim 2,000 \mathrm{~m} l / \mathrm{min}$ の間で 変化させ, 限外滤過圧は $0 \mathrm{mmHg}$ で血液側と 透析液側においてサンプリングし比較検討を行 った。

臨床においては，Blood Flow は $180 \mathrm{~m} l / \mathrm{min}$ とし，透析液は in vitro と同様の方法で変化

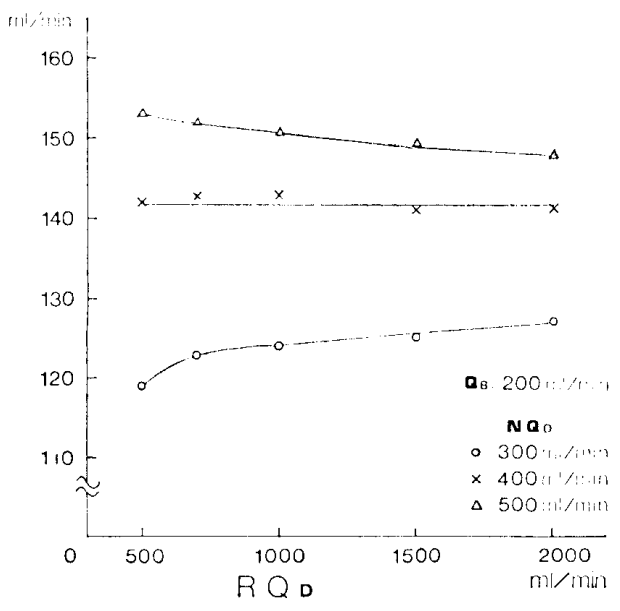

図 2 Urea-N Clearance
医器学 Vol. 48, Suppl. (1978)

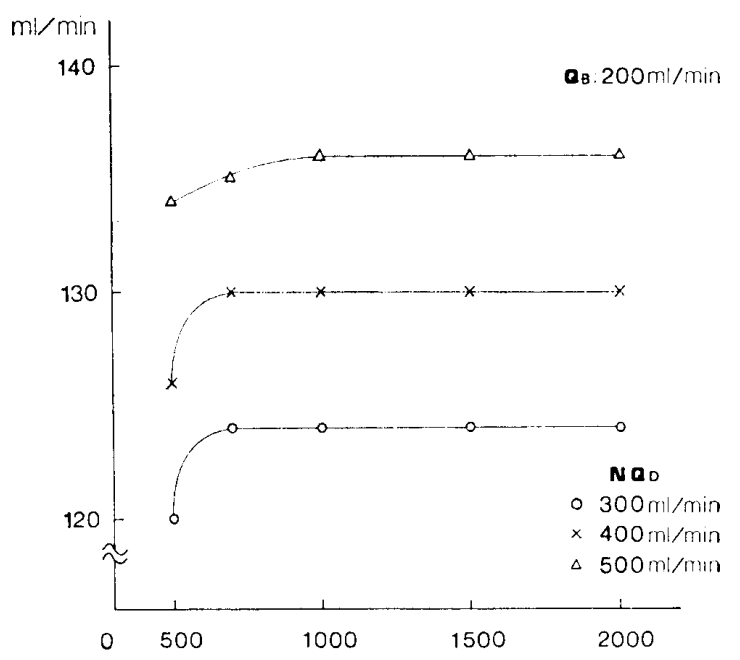

図 3 Creatinine Clearance

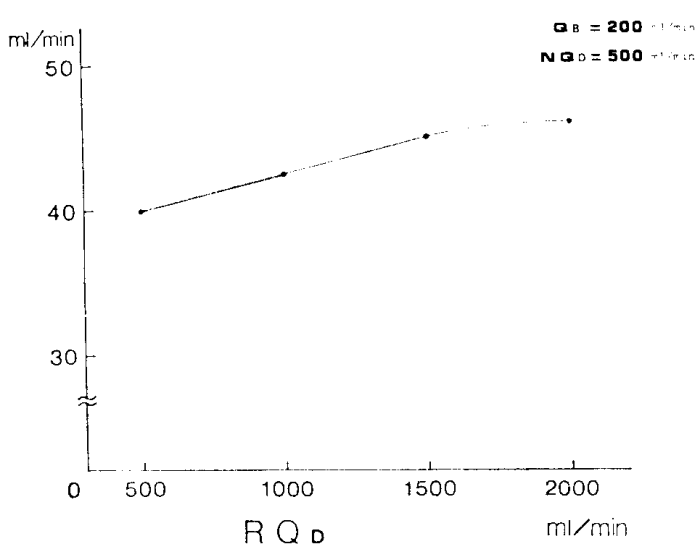

図 4 Vitamine $\mathbf{B}_{12}$ Cleance

させ, 溶質除去能及び臨床症状の変化を検討し た.

\section{成 績}

図 2 と図 3 は尿素窒素及びクレアチニンのク リアランスである。

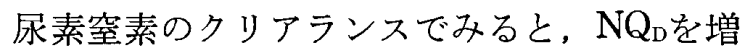
すと明らかに透析の効率は増大するが， $\mathrm{RQ}_{\mathrm{D}}$ 増しても効率は良くならないクレアチニンの クリアランスでも，全く同様の傾向を示した。

図 4 はビタミン $\mathrm{B}_{12}$ のクリアランスを示した。 RQD増すと増加する傾向を示した。

図 5 と図 6 臨床に㧍ける尿素窒素及びクレ アチニンの除去の時間的な経過を示した.

$\mathrm{RQ}_{\mathrm{D}}$ を増すほど除去が緩除に行われ，5時間 透析後の除去率には差がほとんどみられなかっ た.

\section{結 語}

我々が試作した多用途型透析装置を，実験的 及び臨床的に使用した結果, 密閉型及び非密閉 
医器学 Vol. 48, Suppl. (1978)

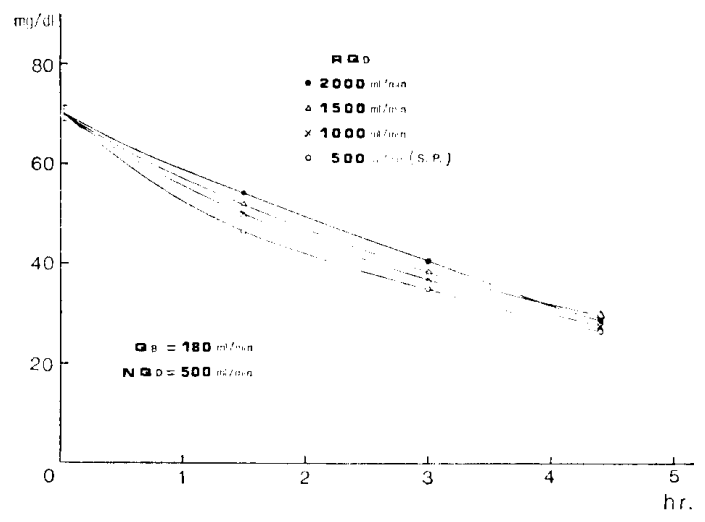

図 5 BUN

型ダイアライザいずれにおいても，全く支障な く使用することができた，更に密閉型ダイアラ イザに対して，透析液を一部再循環させる機構 によって透析を行った場合，S.P. 力式では十 分に利用されないまま捨てられていた透析液を 活用できる結果, Small molecular substance については，S.P.方式と同等の除去能が得ら れる一方, middle molecular substance のク

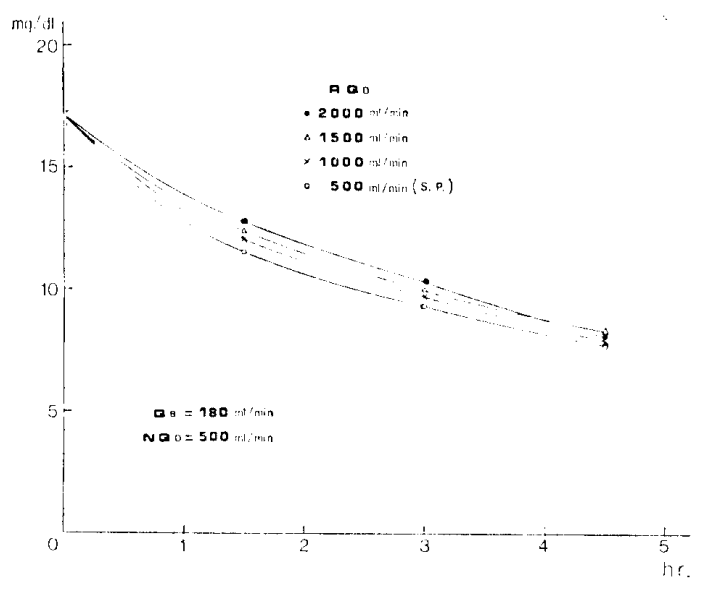

図 6 Creatinine

リアランスは増加した。

また, Small molecular substance の除去が 緩除に行われるために不均衡症候群, 疲労感な どが減少した。

初期透析，大面積ダイアライザの使用，小巟 老人などの透析に㧍いて良好な成績を得るもの と思われる。 